\title{
Between Bioconservatism and transhumanism: In search of a third way
}

Filip Bardziński (Adam Mickiewicz University)

Review of the book by R. Cole-Turner (ed.) Transhumanism and Transcendence: Christian Hope in an Age of Technological Enhancement. Washington, D.C.: Georgetown University Press, pp. 208.

\section{Introduction}

Transhumanism is undoubtedly one of the most important - and most controversial - intellectual movements of the early $21^{\text {st }}$ century. It's reception of the development of biological and computational sciences, as well as the hopeful perspectives it offers, proves how universally important for all humanity are such topics as individual perfection, cultural development, and relations between progress in science and their social reception and application. However, the transhumanist perspective on how to benefit from new technologies (i.e., life extension, enhancing human capabilities, etc.) remains highly controversial, as far as to be called the modern world's most dangerous idea by Francis Fukuyama: "The environmental movement has taught us humility and respect for the integrity of nonhuman nature. We need a similar humility concerning our human nature. If we do not develop it soon, we may unwittingly invite the transhumanists to deface humanity with their genetic buldozers and psychotropic shopping malls" (Fukuyama 2009). Most transhumanists disagree with Fukuyama voice, stating that "the only real danger posed by transhumanism, it seems, is that people on both the left and the right may find it much more attractive than the reactionary bioconservatism proffered by Fukuyama or Leon Kass" (Bostrom 2004).

The "reactionary bioconservatism" Bostrom writes of is often linked with religious - and precisely Christian - thinking and philosophy (see e.g. IEET chart on biopolitics). In general, the Catholic church rejects transhumanism as a whole (see: FIAMC 2013) by pointing out the possible dehumanizing effect it may have, as well as the hubristic desire to remake God's creation according to one's preference. However, it is worth noting that Christian thinkers did not - and do not - dismiss the notion of enhancing human nature entirely and without some reservations. The tome edited by Ronald Cole-Turner proves to the latter by gathering a vast collection of both 
historical and modern Christian theological voices in favor of human enhancement and transhumanism.

\section{Christianity and transhumanism in historical perspective}

The historical research is conducted mostly in the parts written by Michael S. Burdett and David Grumett. In the chapter "Contextualizing a Christian Perspective on Transcendence and Human Enhancement", Burdett explores the philosophical ideas developed by Francis Bacon, Nikolai Fyodorovich Fedorov, and Pierre Teilhard de Chardin, which - as he proves may be seen as a historical Christian foundation for modern transhumanism. As noted on the transhumanist claims present in the thinking of aforementioned philosophers:

It is apparent that there is a tradition within Christian history that does not see the enhancement of humanity through technological means as a particular problem. As we have seen, Bacon advises that his new science would mitigate the effects of the Fall and enhance humanity's dominion over the world. Fedorov claims that death is the ultimate enemy of humanity and that its limitation through technological resurrection should be the aim of humanity and the Christian. Teilhard de Chardin encourages the use of technology to enhance humanity, because he believes that each biological step is advancing toward the cosmic Christ (Burdett 2013, 32).

A more complex insight into possible transhumanist notions in Teilhard de Chardin's philosophy are given by David Grumett. British theologian not only pinpoints the well-known influence Teilhard de Chardin had on Julian Huxley author of the term "posthuman" - but also unveils seven concepts and ideas developed mutually by the early $20^{\text {th }}$ century French Jesuit and modern proponents of transhumanism, such as Ray Kurzweil or Nick Bostrom. This leads Grumett to ascerting that - both Teilhard de Chardin's and transhumanists' - "vision of technology contributing to the realization of God's purpose for the world does not imply naive approval of every technical innovation or process. Instead, it helps to establish a normative standard against which these can and should be judged" (Grumett 2013, 43). It is possible to assert that - to some extent - the proponents of transhumanism do acknowledge some form of metaphysic (as noted by Grumett: "In transhumanist discourse, the moral ends that humans should pursue are set within a general metaphysics" $(2013,42)$, and therefore would accept the notion of a divine being, which may be identified with the concept of clear perfection. 


\section{Christian ethics and transhumanism}

In the succeeding chapters the notions of human and posthuman dignity are being discussed, as well as the relations between transhumanism and the ideas of Christian sin, hope, and gender. Karen Lebacqz dedicated her text to exploring how the concept of human dignity is being constructed in Christian theology and ethics, and attempts to develop a critical understanding whether the competing concept of posthuman dignity, developed explicitly by Nick Bostrom (2005), may be seen as logically sound and worthwhile. After recapitulating the different stances on dignity present in transhumanist and bioconservative thought, Lebacqz makes an attempt on answering the question whether an autonomous Christian response to the notion of enhancement exists - one that would practically differ from those given by Bostrom on one hand and Kass on the other. "Christian theology is at root a "Creation-Fall-Redemption» theology. (...) Within this story, many themes related to the Creation and Fall evoke the notion that limits should be set on human striving and hence, possibly, on enhancement efforts. (...) I argue that Redemption trumps Creation and Fall and therefore permits some latitude for enhancement" (Lebacqz 2013, 55). This response leads Lebacqz directly to assuming that "there is reason to embrace enhancement that takes away pain, death, and limits on human life" (Lebacqz 2013, 58). Although it may seem counterintuitive at first, the American theologian gives several reasons for such an interpretation, e.g. the presage given in the Book of Revelation that in the final days a new Earth and new Heaven shall be restored, in which there will be no more pain and dying. Thus, concludes Lebacqz, the reason for enhancing human nature.

To a different moral aspect points Ted Peters in his chapter "Progress and Provolution. Will Transhumanism Leave Sin Behind?". Although declaring himself sympathetic towards transhumanism - and techno-enthusiasts altogether - as they embrace one of the most precious gifts from God: creativity and desire to transform, he states that a reasonable level of caution towards transhumanist claims is needed: "An item of looming significance is missing from this [transhumanist] vision: a realistic appreciation for the depth and pervasiveness of what theologians call sin. As sinful creatures, we humans never lose our capacity to tarnish what is shiny, to undo what has been done, to corrupt what is pure" (Peters 2013, 64). Peters aim is thus to provide a schematics for how the transhumanist goal - the posthuman future - may be attained and whether it is actually worth achieving. The conclusions Peters draws are not as optimistic as those of Bostrom or Savulescu; the transhumanist ethics - he argues - is torn between a tension between biological and economic concepts of rivalry and "survival of the fittest", and an altruistic and benevolent hope for a better, more-than-humane future. Furthermore, most transhumanists renounce religion as an atavistic and conservative concept. Peters believes that - due to this fact - they are unable to 
notice the difference between technological and eschatological immortality. Thus, the notion of progress becomes problematic, as it is being renounced both by natural sciences and theology: "Many leading evolutionary theorists including Ernst Mayr, Stephen Jay Gould, and Francisco Ayala - refute the notion that progress is built into the process of evolutionary change. (...)The ambiguity [of progress] of which Niebuhr speaks is the ever-present potential created by human freedom, namely, the potential to choose evil and chaos along with what is good and fulfilling" (Peters 2013, 78-79). The conclusion for Peters is thus obvious: improving certain human capacities (e.g. those linked to long and healthy life) is acceptable, whereas other should be greeted with caution and severely limited.

A different topic is discussed by Stephen Garner. Concentrating on the technological rather than biological aspect of transhumanist thought, notably on the cybernetic organisms and their relation to religion. A 'cyborg' may be defined as an organism "typically human, that has had technological artifacts added to its physical being" (Garner 2013, 88). Those artifacts may range from well-known and raising few debates synthetic hip replacements, pacemakers, and heart valves, to highly sophisticated and controversial brain implants, synthetic muscle tissues, and many other. In such sense, it is possible - along with Donna Haraway - to assume that modern people, interacting constantly with technological artifacts and forming bonds with them, are in fact cyborgs to some extent. The question that arises concerns whether such a hybrid organism has a predefined space in Christian theology. Garner brings here the account of Philip Hefner and Anne Kull, who firmly agree that humanity - as being a "created cocreator" - is capable of transgressing it's biological limitations and become a hybrid. It is also possible - they argue - to assume that Jesus Christ was an ultimate cyborg: demi-human and demi-god. Thus, Kull argues that it is impossible to separate physiological and cognitive enhancement from one another. A further notion is given on how Christians assume themselves being "citizens of Heaven", although they live on a different - earthly - plain of existence. From such accounts, Garner argues that there exists a well-grounded tradition for hybridity and cyborgs in Christian theology, one that requires "avenues - in communities of faith, in the academy, and in the public square - for raising, discussing, and answering these questions so as to provide hope in the face of this tension between awe and anxiety" as "hope arises from the theological reflection of the tension between wonder and anxiety, as each informs the other, and drives to the fore essential questions about human technological agency" (Garner 2013, 98).

An even more critical reception of transhumanism is present in research of Jeanine Thweatt-Bates on gender. The feminist theologian, adhering to the understanding of cyborgs developed by Donna Haraway, points out "the significant differences between the cyborg and transhumanist posthuman visions". As elaborated by Thweatt-Bates: 
the transhumanists tend to embrace an anthropological dualism, whereas the «cyberfeminists» embrace a strong materialism. (...) the fact that those engaged in doing Christian theological anthropology have recently begun to appreciate that embodiment opens the door to a theological understanding of the posthuman (...) might helpfully critique the problematic aspects of transhumanist anthropology, including gender (Thweatt-Bates $2013,101)$

The fundamental objection towards transhumanist anthropology, developed by Thweatt-Bates, is thus following: Transhumanists wish to transcend biological constraints (including those of sex/gender) through a controlled enhancement of human capabilities. The posthuman will therefore be able to manifest physiological aspects of either sex, enabling him to live a better, fuller life. However, "in the transhumanist postgender future, bodies may indeed be multiply gendered, but persons will not be" (Thweatt-Bates 2013, 104). The posthuman will seemingly be able to choose from the variety of different gender roles and traits and mold them freely into whatever he desires although a prerequisite state of androgyny is required. Thus the promotion of artificial insemination and artificial pregnancy, that would free the posthuman from the "evil, seductive and limiting biological matter". As Thweatt-Bates points out, this view resembles firmly the Platonic idealistic anthropology; one that has been already vastly discussed in theological debates over past centuries. Thus the liberating case of Christian body theology becomes fully understandable: it offers a well-grounded insight into how and why Platonic idealistic philosophy may impose negative constraints on human development.

\section{Transhumanism and Christian theology}

The notion of transcending biological limitations is discussed also by Celia Deane-Drummond. The desire to part ways with our human physiological and cognitive fragility is one that preoccupies the thoughts of such transhumanist thinkers as Nick Bostrom or John Harris. The latter envisages that - through scientific progress - prolonged life expectancy, along with obliteration of human vulnerability to diseases and removal of psychological, subjective suffering, are the unavoidable consequence of progress. These hopes, although alluring, do possess certain drawbacks: they require technologies that are yet to be discovered, tested, and mastered in order to provide a stable source for posthuman future. And since the use of human subjects in biomedical testing is severely limited, animal subjects will probably remain the sole source of "testing material". This leads to assuming that not only "posthuman" but also "postanimal" are the future of the biosphere. This vision remains uneasy. Through a careful reception of the philosophy of Augustine of Hippo, along with Plato, Descartes, Heidegger, and Paul W. Taylor, Celia Deane-Drummond declares: "For these kinds of thinkers, and I count myself as broadly belonging 
among them, transhuman philosophy of the type peddled by Bostrom fails not just because it seems to promote disconnection within the self (mind and body), while offering a materialistic atheism, but also because it promotes disconnection between selves" (Deane-Drummond 2013, 123). An alternative to transhumanism future is given; one that embraces the need for treating nonhuman animals in a subjective manner, and thus embraces the biological - as well as the cognitive - dimension of personhood and humanity.

The concept of prolonged life is discussed specifically in the chapter "Chasing Methuselah" by Todd T. W. Daly. The prolonged lifespan of human species, being undoubtedly an effect of progress in medical and biological sciences, does not come without moral doubts from some conservative thinkers - while transhumanism embraces this concept as its core statement. Preserving human body from decay and death is not, however, an idea invented recently; Daly dates it to the writings of Saint Athanasius of Alexandria, and later developed by Karl Barth. The ancient doctor of the Church assumed that - if the body is in perfect submission to the soul, and the soul is totally devoted to God - it is possible to postpone aging and death. This notion has been also discussed by Barth, who arrives at interesting conclusions: Jesus Christ was the one true human - "embodied soul and besouled body" - whose existence was thus in perfect harmony. As humans, however, "we allow our body and soul to "go their separate ways,» and thus allow the drives of the body to have undue influence on the soul (...) One of the main characteristics of this body/soul disorder, says Barth, is dissatisfaction with our current life span" (Daly 2013, 138). In consequence, as capable of sin, we wish to extend our lifespan through technological means, distancing ourselves from the Creation and rendering our struggles hopeless. To conquer death, Christianity believes, is to accept it and put faith in God, whom - in his unlimited grace - shall grant us with a long and full life.

To a less spectacular, but nonetheless controversial aspect of transhumanism points Michael Spezio, namely that of enhancing human cognitive and emotional capacities. As Spezio argues, transhumanists demonstrate a negative stance towards emotions, as they believe that strong and negative emotions (such as anger, anxiety, or grief) make humanity weak and vulnerable. Thus the need to eliminate - or at least suppress - such emotions is needed in order to truly enhance human conditions. Spezio, however, tends to the opposite: "Emotion makes us strong, not weak. Eliminating emotion will make us less human, not more human or rational, and certainly not transhuman in any sense of that word that is close to what the strongest advocates of transhumanism envision" (Spezio 2013, 146-147). The need for suppressing negative emotions (e.g. those linked with PTSD) may seem intuitively desirable; yet Spezio demonstrates at this point the theology of Dietrich Bonhoeffer, who "as one who took seriously the need to see humans as they are, he made relationality central to his theology and his theological 
anthropology. [This aspect] provides useful and reasoned opposition to transhumanist views that have an unrealistic or anemic view of the human and of the complexity of human society" (Spezio 2013, 152). The relational aspect of human behavior is constituted on our emotional life both in its positive and negative dimension. "Liberating" ourselves from certain emotions would in fact pauperize humanity rather than enrich it, since purely rational reasoning does not enable such morally valuable attitudes as empathizing with others concludes Spezio.

In the following chapter "Whose Salvation? Which Eschatology? Transhumanism and Christianity as Contending Salvific Religions" by Brent Waters, the notion of transhumanism as a secular religion is discussed. As Waters assumes, transhumanism perceives modern biological human condition as limiting and thus should be overcome - as humanity has been up until now been overcoming other biological restraints. In effect, the posthuman future is something that is not only desirable for itself, but also a future that falls into a logic of universal and teleological progress and one which may be perceived as the fruit of humanity struggles. In a world that permits a lifespan of over two centuries, the need for an eschatological hope is thus severely diminished. Such hope, however, is false, claims Waters, taking as an example Max More's philosophy of human enhancement: "More's salvific scheme is quixotic. (...) He believes that individuals can refashion themselves into the kind of beings they want to become (...). His ideal self exemplifies the autonomous individual, which means that he is appealing to a historically conditioned tradition rather than any so-called pure rationality. The eventual posthuman, then, is little more than a hyperlibertarian" (Waters 2013, 169). In effect, More's faith in posthumanity offers nothing more than the successful application of modern technologies into liberating schemes known since Robert Nozick's "genetic supermarket." "Christian theology cannot embrace the transhumanist salvific strategy and eschatological horizon for reasons that are similar to its earlier rejection of the Manichean and Pelagian heresies", as Waters concludes (Waters 2013, 170-171), namely the Manichean vilification of material body and the Pelagian belief in the human self-perfecting capabilities.

In the two final chapters, Gerald McKenny and Ronald Cole-Turner discuss precisely how does Christian transcendence and transhumanism link with each other. What is important to note is the fact that both Christian theology and transhumanism embrace the claim that superhuman capacities those which transcend human nature - are of intrinsic worth and thus should be pursued not only as means to an end, but as ends in themselves. However, the difference lies whether such aims are attainable and at what cost. As noted by McKenny:

transhumanists and humanistic naturalists are in agreement that the enjoyment of goods that transcend our natural human capacities must come at the cost of these capacities and therefore 
of our humanity. (...) It is just this assumption, however, that Christian theology rejects in its conception of communion with God. (...) Moreover, although these capacities must be extended in order to enjoy this good, it is the gift of divine grace that extends them, and not a technological enhancement (...). Finally, although the ultimate good exceeds human capacities, it is still a human good, a good for humans, and the external transcendence made possible by divine grace, far from denigrating humanity, is what makes it possible to enjoy this good, which infinitely exceeds and overwhelms our capacities, while we remain human (McKenny 2013, 184-185).

A parallel concept of perfectionism (self-development) and meliorism (technological enhancing interventions) has been also developed by Catholic German philosopher Robert Spaemann (1999). In consequence, both authors defend the view that human nature "as it exists today was not created in its present form". That is why they dismiss the belief that "human nature should be seen as fixed and final and that it is either impossible or inherently immoral to try to change it" (Cole-Turner 2013, 193-194). Although Christian theologians share altogether the critique of transhumanism - as cited above yet they do present different stances on whether and to what extent are human capable of transcending themselves. This matter proves to yet be developed in a more deep and full manner.

\section{Conclusion}

To assert that transhumanism has no links to religion or transcendence is obviously false. As shown by the aforementioned authors, however, these relations surpass simple statements that transhumanism is a form of modern laic religion. The numerous ways in which transhumanist thinkers both derive from Christian theology and philosophy, and are critically received by theologians and religion philosophers, provide a broad and stimulating insight into contexts that often remain underexplored or even unidentified.

\section{References}

Bostrom, N. 2004. "Transhumanism: The World's Most Dangerous Idea?" Foreign Policy October $19 . \quad$ URL: http://www.nickbostrom.com/papers/dangerous.html.

Bostrom, N. 2005. "In Defence of Posthuman Dignity." Bioethics 19(3): 202-214.

Burdett, M. S. 2013. "Contextualizing a Christian Perspective on Transcendence and Human Enhancement." In: Cole-Turner, R. (Ed.) Transhumanism and Transcendence: Christian Hope in an Age of Technological Enhancement. Washington, D.C.: Georgetown University Press: 19-35. 
Cole-Turner, R. 2013. "Transhumanism and Christianity." In: Cole-Turner, R. (Ed.) Transhumanism and Transcendence: Christian Hope in an Age of Technological Enhancement. Washington, D.C.: Georgetown University Press: 193-203.

Daly, T. 2013. "Chasing Methuselah. Transhumanism and Christian Theosis in Critical Perspective." In: Cole-Turner, R. (Ed) Transhumanism and Transcendence: Christian Hope in an Age of Technological Enhancement. Washington, D.C.: Georgetown University Press: 131-144.

Deane-Drummond, C. 2013. "Taking Leave of the Animal? The Theological and Ethical Implications of Transhuman Projects." In: Cole-Turner, R. (Ed.) Transhumanism and Transcendence: Christian Hope in an Age of Technological Enhancement. Washington, D.C.: Georgetown University Press: 115-130.

Fukuyama, F. 2009. "Transhumanism." Foreign Policy October 23. URL: http://foreignpolicy.com/2009/10/23/transhumanism/.

FIAMC. 2013. Madrid Declaration on Science and Life. URL: http://www.fiamc.org/bioethics/madrid-declaration-on-science-life/.

Garner, S. 2013. “The Hopeful Cyborg.” In: Cole-Turner, R. (Ed.) Transhumanism and Transcendence: Christian Hope in an Age of Technological Enhancement. Washington, D.C.: Georgetown University Press: 87-100.

Grumett, D. 2013. "Transformation and the End of Enhancement." In: ColeTurner, R. (Ed.) Transhumanism and Transcendence: Christian Hope in an Age of Technological Enhancement. Washington, D.C.: Georgetown University Press: 37-49.

Lebacqz, K. 2013. "Dignity and Enhancement in the Holy City." In: Cole-Turner, R. (Ed) Transhumanism and Transcendence: Christian Hope in an Age of Technological Enhancement. Washington, D.C.: Georgetown University Press: 51-62.

McKenny, G. 2013. "Transcendence, Technological Enhancement, and Christian Theology." In: Cole-Turner, R. (Ed.) Transhumanism and Transcendence: Christian Hope in an Age of Technological Enhancement. Washington, D.C.: Georgetown University Press: 177-192.

Peters, T. 2013. "Progress and Provolution. Will Transhumanism Leave Sin Behind?" In: Cole-Turner, R. (Ed.) Transhumanism and Transcendence: Christian Hope in an Age of Technological Enhancement. Washington, D.C.: Georgetown University Press: 63-86.

Spaemann, R. 1999. "Genetic Manipulation of Human Nature in the Context of Human Personality." In: de Dios Vial Correa, J., Sgreccia, E. (Eds.) Human Genome, Human Person and the Society of the Future: Proceedings of the fourth Assembly of the Pontifical Academy for Life. Vatican City: Libreria Editrice Vaticana: 340-352.

Spezio, M. 2013. "Human or Vulcan? Theological Consideration of Emotional Control Enhancement." In: Cole-Turner, R. (Ed.) Transhumanism and 
Transcendence: Christian Hope in an Age of Technological Enhancement. Washington, D.C.: Georgetown University Press: 145-162.

Thweatt-Bates, J. J. 2013. "Artificial Wombs and Cyborg Births". In: Cole-Turner, R. (Ed) Transhumanism and Transcendence: Christian Hope in an Age of Technological Enhancement. Washington, D.C.: Georgetown University Press: 101-114.

Waters, B. 2013. "Whose Salvation? Which Eschatology? Transhumanism and Christianity as Contending Salvific Religions." In: Cole-Turner, R. (Ed.) Transhumanism and Transcendence: Christian Hope in an Age of Technological Enhancement. Washington, D.C.: Georgetown University Press: 163-175. 
Filip Bardziński (Adam Mickiewicz University)

Abstract: Review of the book edited by R. Cole-Turner Transhumanism and Transcendence: Christian Hope in an Age of Technological Enhancement.

Keywords: transhumanism, theology, transcendence, Christianity, Bostrom.

Ethics in Progress (ISSN 2084-9257). Vol. 6 (2015). No. 1, pp. 153-163.

doi: 10.14746/eip.2015.2.9 